\title{
THE FRAMEWORK OF TEACHING LEARNING PROCESS OF INDONESIAN NATIONAL QUALIFICATION IN PRIVATE COLLEGE
}

\author{
${ }^{1}$ Chontina Siahaan, ${ }^{2}$ Hendry Sinuraya, ${ }^{3}$ Donal Adrian \\ ${ }^{1,2,3}$ Communication Science, Universitas Kristen Indonesia, Jakarta \\ I'chontina.siahaan@uki.ac.id, ${ }^{2}$ hendry.sinuraya@uki.ac.id ${ }^{3}$ Donal.adrian@uki.ac.id
}

\begin{abstract}
The Indonesian national qualification the education system is still relatively new, Universitas Kristen Indonesia but as educators, were required to be able to exercise a marksman in conveying the, learning attractive easy to understand and give the opportunity for message receiver to express his response to a clarification on a subject discussed. A research paradigm is constructive. The kind of research is qualitative. The result showed that strategy lecturers in conveying a message or material college-based Indonesia national qualifications framework in Universitas Kristen Indonesia do with how to explain back material that has delivered, use simple sentences and give a case that up to date.
\end{abstract}

Keywords: The learning process, education communication, Indonesian national qualification

DOI: 10.33541/sp.v19i1.1641

Sociae Polites : Majalah IImiah Sosial Politik

Faculty of Social and Political Science, Universitas Kristen Indonesia

ISSN 1410-3745 print/ ISSN 2620-4975 online

Volume 19, Number 1 (January - June 2018)

Pages 53-65 


\section{Introduction}

Of course, education must have good quality. According to the level and development of society in the world of work, the variety of programs and educational outcomes that can meet expectations. Lecturers try to provide learning services that give satisfaction to the students. The leadership of the educational institution offers comfort to the lecturers and other education personnel, and in overall institutional performance provides joy to the community and the world of work. The quality of higher education institutions is the totality of conditions and characteristics of inputs, processes, and products or services of tertiary institutions measured from several standards as a benchmark of assessment to determine and reflect the quality of tertiary institutions.

Based on the written rules regarding the quality of education explained that in article 1 paragraph 17 of RI Law Number 20 of 2003: "National education standards are the minimum criteria about the education system in all jurisdictions of the Unitary Republic of the Republic Indonesian. " Regarding the minimum criteria for national education standards consisting of content standards, processes, graduate competencies, education personnel, facilities and infrastructure, management, financing, and education assessment that must improve in a planned manner (Article 35 paragraph 1 of RI Law Number 20 of 2003). The goal is to achieve a better and more beneficial education. However, based on the reality that is happening in the world of a college education. It is high that there are still many tertiary institutions with a deficient quality of education.

In a scientific journal by M. Rosul Asmawi related to "Strategies to Improve Quality Graduates in Higher Education." Also, it explains that the low quality of education in Higher Education can look from graduates who are not always able to accept and can work as expected by the world of work. The rise of college the high potential for a decline in the quality of graduates, given the standardization of graduate quality, is not an objective; but only in terms of quantity, namely how to get as many students as possible. Likewise, with the implementation of autonomy campus, where the state (PTN) and private (PTS) universities have similarities in management, so there is a tendency to find adequate funding; however, sometimes ignores the quality aspect itself. (Makara, Social Humanities, Vol. 9, No. 2, December 2005, 66-71)

Besides, it was added again related to the crucial problems of the Indonesian people, in general, referring to the low quality of education in the 21st century. The low quality of knowledge can look in the data in Education for All (EFA) Global Monitoring The 2012 report released by UNESCO reported that Indonesia was ranked 64th out of 120. In the Education Development Index (EDI) assessment, on March 14, 2013, it was said to have risen three places to 121 st place out of 185 countries. This data includes aspects of labor, health, and education. Judging from the rank, it does show an increase, but when viewed from the number of participating countries, the result is that Indonesia still does not rise in status. (Oktriany et al., 2015: 2) Problems related to the low quality of education in Indonesia, especially at the level of tertiary education, both public and private.

And of course, it becomes a massive concern for the government so that in the process, the government then implements a new program in education standards in Indonesia called the Qualification Framework Indonesian National (KKNI). Referring to Permendikbud No. 73 of 2013 concerning the application of the IQF in the field of higher education, tertiary institutions, through the Study Program, need to compile a description of learning outcomes at a minimum referring to the level of the IQF. Learning 
achievements are abilities acquired by internalizing knowledge, attitudes, skills, competencies, and accumulated work experience. So that way, study programs with all the resources owned, multitrack, and multimethod, striving for the realization of learning outcomes. After ascertaining the formulation of learning outcomes, the next step is to develop, implement, and evaluate a curriculum that refers to the IQF. Finally, develop an internal quality assurance system to ensure the learning outcomes that have been set (Maximum 2015).

Universitas Kristen Indonesia (UKI) in Jakarta also applies the Indonesian National Qualification Framework (KKNI) used by the government as a guideline for achieving the quality of education, in its implementation. Considering that KKNI is still relatively new at the UKI, then as educators, lecturers are required to be able to implement the right strategies in delivering learning material (messages) that are attractive, easy to understand and provide opportunities for recipients to provide equipment his response or clarification of a problem discussed. If the discussions that occur between lecturers and students take place well, then it is certain that the student who receives the message is able to use his critical thinking. Conversely, if the communication or discussion goes smoothly, which involves more lecturers as speakers, then students who receive messages do not use critical thinking and certainly do not give heavyweight to the messages received. Also, to seeing from the side of the communicator, the meaning of the word can work well if supported by excellent educational facilities. Still, on the contrary, the purpose of the message will not run well. When the educational facilities are very far from the set standards, for example, the number of seats is not proportional to the number students in one class, LCD is still lacking, telecommunications networks that do not work optimally, and others.

Based on the above background, the formulation of the problem in this study are: (1) What is the lecturer's strategy in delivering messages in the form of learning materials based on the Indonesian National Qualifications Framework (KKNI) to students of Indonesian Christian University? and (2) How is the availability of facilities to support the teaching and learning process based on the Indonesian National Qualification Framework (KKNI) at UKI?

\section{Literature Review}

\subsection{Instructional Communication / Educational Communication}

Instructional communication means communication in the instructional field. Instructional communication is part of scholarly communication, which is a communication process that is patterned and specifically designed to instill the target party (communicant) in the event of a change in behavior that is better in the future. Changes in behavior are intended primarily in aspects of cognition, affection, and kinase or psychomotor (M. Yusuf Pawit 2010). Communication in this instructional system, its position is returned to its original function, namely as a tool to change the target's behavior (educative).

Yusuf (1989) explained that communication in this instructional system developed its position to its original function, as a tool to change the target behavior of students. The communication process created naturally, intimate, and open with the support of other supporting factors, both in terms of facilities and other facilities, to have the effect of behavior change on the target parties. The communication process can divide 
into a set of steps consisting of content specifications and goals or objectives for the interpretation of the initial behavior, the determination of strategy, the organization of instructional units, and feedback.

\subsection{Teaching and Learning Process}

According to Syafaruddin $(2002,34)$ in his book Integrated Quality Management in Education Concepts, Strategies and Applications, stressed that the teaching. Also, the learning process is: "The process that occurs faithfully the day in an educational institution, both elementary school, secondary school, high school or higher school that is higher education that is managed by universities. Teaching and learning is a process of synergy between students as teaching objects (knowledge) and the teacher as a source of subjects after going through various ways of reading, formulating material, and so on to be used as teaching material. The process of interaction both in the classroom also outside the school. Also, it is from now on referred to as the teaching and learning process. In Communication Science, the material presented in the teaching and learning process based on the Indonesian National Qualification Framework (KKNI) is referred to as a message. According to Orbe \& Brues (2005) (in Liliweri 2011) states that words are ideas, feelings, or thoughts that have been encoded by the sender or decoded by the recipient. According to DeVito (1986), messages in the form of signals, symbols, signs. Also, a combination of them all and function as a stimulus to be responded by the recipient.

\subsection{Plan Theory}

Charles Berger (1997) is the originator of the theory of plan (theory of planning) as one of the methods known in Communication Science. Plan theory explains the process a person goes through in planning their communication behavior. Berger states that plans are "hierarchical cognitive representations of goal-directed action sequences." The meaning is that (a hierarchical cognitive representation of the sequence of actions directed at the goal). In other words, a plan is a mental image (mental images) of several steps that someone will take to achieve a goal. The steps to be passed are hierarchical or tiered because specific actions are needed first so other measures can take it. Thus planning (planning) is the process of thinking about various plans of action.

\subsection{Conversation Analysis Theory}

In this study, the authors used a Conversation Analysis (CA) to see and describe the communication process between lecturers and students when carrying out teaching and learning processes based on KKNI at the UKI in Jakarta. The Conversation is seen as a successor for social achievement (social achievement) because the Conversation requires participants' Conversation to accomplish several things that are done cooperatively throughout the Conversation. (Little John, 2011: 194). CA strives to find in detail and precisely what success has been achieving by testing various notes (transcripts) of Conversation. Here, carefully watched every action taken in Conversation and also examine what the speaker is doing when they communicate. How do communicators ask questions, how do communicants answer? How to turn to speak and how facial expressions. The point is knowing how things were done in the language. What kinds of devices and interactions do the parties involved in the conversation use to produce action? 
CA does not discuss individual differences or mental processes in a person but focuses on what happens in language, on text, or Conversation.

\subsection{Educational Facilities}

Educational facilities are supporting facilities in the teaching and learning process. Means are all things that can use as a tool in achieving goals and objectives. Quality education requires the availability of adequate facilities and infrastructure. Educational facilities are facilities that are used directly in the learning process so that learning objectives are achieved, such as buildings, classrooms, tables, chairs, and learning media tools. While educational infrastructure is anything that indirectly supports the educational process, such as gardens, courtyards, parks, and roads are leading to campus/school. Educational facilities and infrastructure play an essential role because the quality of education can improve through the provision of facilities and infrastructure. In his book Heryati and Muhsin (2014: 195) that the government, through the minister of education, issued Government Regulation No. 24 of 2007 concerning standards for facilities and infrastructure. Facilities and infrastructure standards based on PP No. 19 of 2005 regarding "Standards National Education is an educational standard related to the minimum criteria regarding learning spaces. Also, places to exercise, places of worship, libraries, laboratories, workshops, places to play, places to be creative and recreation, as well as other learning resources, needed to support the learning process, including the use of information and communication technology.

According to E. Mulyasa (2003, 49), educational facilities are tools and equipment that are directly used and support the educational process, especially teaching and learning methods, such as buildings, classrooms, tables, and chairs, as well as teaching tools and media. Then according to B. Suryosubroto (2004: 114), educational facilities are all the facilities needed in the learning process, both moving and not move so that the achievement of educational goals runs smoothly, regularly, effectively, and efficiently. Meanwhile, according to the Drafting Team of the Educational Media Standardization Guidelines of the Ministry of Education and Culture cited by Hartati Sukirman et al. $(1999,28)$. Also, what is meant by educational facilities are all the facilities needed in the teaching and learning process, both moving and not moving so that the achievement of educational goals can run smoothly, regularly, effectively, and efficiently.

\subsection{Indonesian National Qualification Framework (KKNI)}

The Indonesian National Qualification Framework or abbreviated as KKNI regulated in the Presidential Regulation of the Republic of Indonesia Number 8 of 2012. "KKNI" is an embodiment of the quality and identity of the Indonesian people related to the national education system, a federal job training system and a national equality assessment system, which is owned by Indonesia to produce human resources from learning achievements, which are owned by each Indonesian workers in creating quality work and contributing quality in their respective fields of work, (Santoso 2015, 4)

The Indonesian National Qualification Framework (KKNI) sets the measurement parameters in the form of qualification levels from the lowest degree 1 to the highest level 9. Article 5 of Presidential Regulation No.8 of 2012 (concerning KKNI) states that each level of KKNI is commensurate with the level of learning achievement (CP) of study programs at certain levels the equivalent set forth as follows: 

A. Necessary education graduates equivalent to level 1
B. The lowest secondary education graduates equal to level 2
C. The most economical Diploma 1 graduates are equivalent to level 3
D. The most moderate Diploma 2 graduates are equivalent to level 4
E. The lowest Diploma 3 graduates are equal to level 5
F. Diploma 4 or Applied Bachelor and Bachelor graduates with a minimum of 6 degrees;
G. Graduates of the Applied Masters and the lowest Masters are equivalent to level 8
H. Applied Doctoral and Doctoral graduates are equal to 9th level
I. Professional education graduates equivalent to level 7 or 8
J. Specialist education graduates equivalent to level 8 or 9

\section{Research Methods}

The paradigm used in this study is the constructivist paradigm. The constructivist model is a paradigm that is almost the antithesis of understanding, which places observations and objectivity in discovering a reality or science. This paradigm views social science as a systematic analysis of socially meaningful action through direct and detailed inspection of the proper social behavior creating and maintaining/managing their social world (Hidayat, 2003: 3). This type of research is qualitative. The primary purpose of using descriptive qualitative is to describe the nature of a situation that existed at the time the study conducted and explore the causes of specific symptoms. Sevilla $(1993,91)$

In this study, the sampling/informant technique used by accidental sampling is a sampling technique based on coincidence, ie. Also, anyone who accidentally meets a researcher can be used as a sample if it deemed that the person responded by chance is suitable as a source of data (Sugiyono 2001, 60). In this case, the researcher will take samples/informants consisting of lecturers and students of the class 2016 at the Indonesian Christian University (UKI) Jakarta. The informants numbered (a) 12 lecturers and (b) 15 students consisting of 5 faculties at UKI.

\section{Delivery Strategy (KKNI)}

\section{A. Setting up Referral Resources}

The teaching and learning process is based on the Indonesian National Qualification Framework (KKNI) implemented by the Indonesian Christian University in Jakarta. Also, it requires lecturers to be able to work extra hours to produce successors of the nation who excel and, of course, be able to compete in the modern era now. To be able to achieve these objectives, the lecturer applies various strategies in communicating or delivering related messages with lecture material taught to students. Following is the statement from Ms. Formas that: "So that students can better understand the lecture material I teach, so I tell students to prepare reference books or journals as known sources the truth. The point is that students understand and are comfortable too in carrying out KKNI-based lectures. " (Results Interview March 16, 2018)

\section{B. Re-explain Material Delivered to Students}


To be able to provide an excellent understanding to students, the teaching and learning process carried out by lecturers is related to the application of learning models for individual assignments and group assignments. The strategies carried out by lecturers are explained and rectify erroneous statements when students tell. Following is the presentation from Ms. Elferida Sormin that: "The point is that students must be active in the classroom during the learning process teaching takes place, for example actively being presenters with a presentation learning model. I was a lecturer will judge my students and students. But if something is then wrong or wrongly said, then I re-align it so they can be more understand and understand. " (Interview Results March 15, 2018)

\section{Using Simple Sentences}

Simple sentences are a form of delivering messages using words that are often heard and spoken by everyone, both lecturers and students. Simple sentences are considered capable of providing understanding to each individual, especially to students. Therefore, many lecturers apply the learning process based on the Indonesian National Qualification Framework (KKNI) by using a message delivery strategy/lecture material using simple sentences. Following is the presentation from Dr. Bintang Simbolon M.Si argues:

"I often use simple sentences that are easily understood by students, what's more for new students even to the next semester students. I prefer simplifying words with the aim of students becoming understood when receiving lecture material. " (Interview Results March 12, 2018)

\section{Give Cases Up To Date}

The strategy of delivering messages/lecture material by lecturers to students can be finishing by raising various kinds of social causes that are happening in the community. The case gives students and then discussed to find a solution. Following is the submission from Mr. Budi Chrismanto Sirait explaining that: "I always give examples of cases that are up to date, so that students immediately understand, because they witnessed the cases themselves well through any media." (Interview Results March 15, 2018)

\subsection{Facilities and Infrastructure}

Facilities and infrastructure are the most critical part of supporting the success of the teaching and learning process based on the Indonesian National Qualification Framework (KKNI) at the UKI Jakarta. However, based on reality, there are still many facilities and infrastructure found in the faculties of the UKI. Also, that is not yet feasible. Also, do not support the success of the teaching and learning process well, such as:

\section{- Classrooms and Chairs}

The main facilities that are very influential in the KKNI-based teaching and learning process are the classrooms and the number of seats. Learning comfort and student's level of understanding related to lecture material will influence by the feasibility 
of the school and the number of seats available. The following are interviews from research informants at the Indonesian Christian University (UKI).

Formas argued: "The current condition of facilities and infrastructure is still inadequate because in terms of classrooms there are still many borrowing equipments from other classes. Hopefully, later it can be adequate so that the learning process based on KKNI runs smoothly. " (Interview Results March 16, 2018)

- Infocus (LCD)

Infocus (LCD) is a modern tool used by lecturers in the teaching and learning process with students in the classroom. This tool helps students to be able to directly read lecture material delivered by lecturers through the learning model using power points so that the process of knowledge exchange can take place correctly. However, based on the available evidence, some of the LCD devices in the UKI suffered damage so that their use was not optimal, which in the end, the teaching and learning process became less efficient. In terms of facilities and infrastructure, there are many, for example, LCD. It isn't using as a tool to help us explain lecture material to students. Still, the reality is that some LCDs broken, for example, the lighting is reduced, and the image is blurry, then the remote also disappears. " (Interview Results March 14, 2018)

\section{- Air Conditioner (AC)}

Another factor used as a support for the success of the teaching and learning process based on the Indonesian National Qualification Framework (KKNI) at the UKI in Jakarta is the air conditioner (AC). The tool serves to regulate air temperature.

In the classroom so that students and lecturers become comfortable in carrying out lectures. However, currently, in some classes, there are temperature regulators (AC) that cannot function well. Evita and Carolin explained: "Sometimes what makes us as students cannot concentrate on studying. That's because the room is hot. After all, AC doesn't work well. It can no longer set the room temperature to be cool. Finally, well, if we study, we don't focus well on presentations and discussions in class." (Interview Results March 29, 2018)

- $\quad$ Internet (WIFI) and Library

Internet and library networks are indeed very much needed by lecturers and students in finding various kinds of information related to lecture material. Also, or educational information about researches that wrote in the form of journals or the latest output books that discuss theories, concepts, and practices. It can help the academic community in applying lectures based on the Indonesian National Qualification Framework (KKNI) at the Indonesian Christian University in Jakarta. Carolin argues: "In my opinion, sir, that the internet network needed in the current era. Because we can also be smart from what we read via the internet, now, if the internet is always problematic, of course, we cannot access various kinds of information such as information course material that we need. " (Interview Results March 29, 2018)

- Toilet 
The toilet is a compelling means for the activities of students and lecturers in general. Therefore, the cleanliness of the bathroom must be considered and maintained correctly. So it can cause comfort for anyone, especially in the academic community at the Indonesian Christian University in Jakarta. Lala believes: "Honestly, bro, the toilets here are still very far from cleanliness, there is still much rubbish found which certainly can make us uncomfortable. because we humans have disgust because the bathrooms are dirty. " (Interview Results March 28, 2018)

\section{- Canteen}

A canteen is a place for students and lecturers to meet their primary needs, namely food. To be able to provide comfort to students and lecturers, of course, Cantonese hygiene must appropriately maintain. However, currently based on the reality that happened that the campus canteen was still far from clean. Lala explained: "What worries about it is the canteen too. It's dirty, brother. And also, the hygiene of the food is less hygienic. Make it also affects our health. Dirty the canteen can see from the rubbish that just thrown away. " (Results Interview March 28, 2018).

The Indonesian National Qualification Framework (KKNI) is the main guideline used by almost all universities in Indonesia in the teaching and learning process. One example of a university that applies it is the UKI Jakarta. On the campus, lectures carried out between lecturers and students are certainly part of the process of exchanging educational information that aims to increase knowledge and can support students' careers when they become scholars to be able to compete well in the current era of globalization.

The process of exchanging information between lecturers and students is by the concept of communication, according to Effendy (2003: 60). The state's interface is the process of delivering a message in the form of a meaningful symbol as a blend of thoughts. Also, and feelings in the way of ideas, information, beliefs, hopes, appeals, and

so on. Someone to others, both directly, face to face or indirectly through the media, to change attitudes, views, or behavior.

In delivering lectures based on the Indonesian National Qualification Framework (KKNI) at the UKI Jakarta, of course, each lecturer has his strategy towards students. The goal is to make students as recipients of educational material or messages can better understand and be able to apply them in everyday life.

Instructional communication that occurs between lecturers and students aims to be able to broaden students' knowledge through lectures based on the Indonesian National Qualification Framework (KKNI) taught. In the ongoing lecture process, lecturers, as information centers, must, of course, have a strategy in delivering messages/lecture material. The research findings explained that the approach undertaken by the lecturer is to prepare a referral source, re-explain the article offered, using simple sentences, and giving up-to-date cases. The primary purpose of making this strategy is to provide an excellent understanding of students. The findings of the research above are related to the lecturers' approach, of course, also involving students because the messages conveyed must be responded to by students as KKNI-based lecture demands that require student activity. The communication process that occurs between lecturers and students is undoubtedly part of the Conversation that can arise because there is a cause, for example, discussing an up-to-date case that is also commented on by students either providing solutions or raising questions. Scholarly communication that occurs between lecturers 
and students according to the explanation in the theoretical Conversation Conversation is seen as a successor social achievement (social achievement) because the Conversation requires conversation participants to complete several things that are done cooperatively throughout the Conversation. (Little John, 2011: 194).

The findings of the research are related to the lecturers' strategy in delivering lecture material, such as explaining again the material presented is part of the positive attitude of lecturers who want that students must understand and understand the lecture material. This attitude or behavior can undoubtedly reflect in the lecturer's communication delivery process. The research findings are by the indicators of the conversation theory delivered by Paul Grice, which is about maxim manner or behavior when saying that is related to the attitude or practice of a person when conversing.

In the second research findings, namely, using simple sentences related to the indicators of conversation theory delivered by Paul Grice explains that the quantity maxim or the number of words in a conversation, that is, the many terms used in a conversation. In an interview should be used just enough words, not excessive. It means that lecturers who provide lecture material should use simple sentences so that it is easy for students to understand. Furthermore, the third research finding is to provide up-todate cases, meaning that students and lecturers discuss.

These findings are the following indicators of quality maxim. The importance of the truth of the words is used in a conversation. The words that spoken must be something real. Honesty considered very importantly, in an interview. The purpose of the sentence is the problem (case) given by the lecturer to students is indeed a problem that occurs and can look from various sources either through the mass media or even through new media.

Regarding facilities and infrastructure in lectures based on the Indonesian National Qualification Framework (KKNI) at the UKI, Yusuf (1989: 22) explains that communication in this instructional system developed to its original function, as a tool to change the target behavior of students. The communication process created naturally, intimate, and open with the support of other supporting factors, both by means and other facilities, to have an effective behavior change on the part of the target. The communication process can be divide into a set of steps consisting of content specifications and goals or objectives for the interpretation of the initial behavior, the determination of strategy, the organization of instructional units, and feedback. Research related to facilities and infrastructure at the Indonesian Christian University (UKI) in Jakarta does not support the lecture process based on the Indonesian National Qualification Framework (KKNI). It looks in the research findings that contained inadequate classrooms, inadequate classroom chairs, LCD that displays blurred images, air conditioner (ac), which cannot regulate room temperature properly, internet networks that are often problematic. Also, and libraries with books the reading is very lacking, toilets are still filthy, and the campus canteen is not clean, and food is not hygienic.

Problems related to the facilities and infrastructure are certainly very disturbing lecturers and students in carrying out teaching and learning processes based on the Indonesian National Qualification Framework (KKNI). It proves that the campus cannot provide maximum service so that the academic community is disappointed when viewed in terms of the full concept of educational facilities. Also, of course, it is very much different from what found in the results of research. According to E. Mulyasa (2003: 49), educational facilities are tools and equipment that are directly used and support the educational process, especially teaching and learning methods, such as buildings, classrooms, tables, and chairs, as well as teaching tools and media. Then according to B. 
Suryosubroto (2004: 114), educational facilities are all the facilities needed in the learning process, both moving and not moving so that the achievement of educational goals runs smoothly, regularly, effectively, and efficiently.

Meanwhile, according to the Drafting Team of Education Media Culture Standardization Guidelines Department of Education and Culture cited by Hartati Sukirman et al. (1999: 28). What is meant by educational facilities are all the facilities needed in the teaching and learning process, also both moving and which does not move so that the achievement of educational goals can run smoothly, orderly, effectively, and efficiently?. Furthermore, based on the communication science perspective that unfulfilled expectations related to not being realized maximally for facilities and infrastructure services will undoubtedly make the communication process ineffective.

\section{Conclusions \& Recommendations}

Based on the research findings that have been analyzed in-depth related to "Communication Education Based on the Indonesian National Qualification Framework (Qualitative Study on the Communication of Lecturers and Students in the Teaching and Learning Process at UKI). Also, the conclusion in this study is that the lecturers' strategies in conveying messages or material The framework of the Indonesian National Qualification Framework (KKNI). Based at the UKI, Jakarta already by making several lecture preparations that are part of the initial planning, such as learning to read books and research journals, preparing a Semester Learning Plan (RPS), and making PowerPoint Presentations. Next, in delivering the message, the lecturer explains the material that has given, uses simple sentences, and provides an up to date case.

Researchers suggest that scholarly communication or instructional communication based on the Indonesian National Qualification Framework (KKNI) at the UKI Jakarta that occurs between lecturers and students can be further enhanced, especially in the process of sharing knowledge. We hope that the UKI Jakarta will prepare more optimally in implementing education communication based on the Indonesian National Qualification Framework (KKNI) because there is a faculty such as the Faculty of Economics. Who does not implement KKNi-based learning programs due to many small things, such as campus facilities and infrastructure?

Campus facilities and infrastructure must, of course, be able to be repaired and, if necessary, be replaced with something new, either damaged classrooms. Also, there are insufficient chairs, student numbers, LCD, which is still lacking and often displays blurred images, temperature regulators that do not function properly, and so forth. 


\section{BIBLIOGRAPHY}

\section{Books}

Azwar,Saifudin. 2007. Metodelogi Penelitian. Pustaka Belajar: Jakarta

B. Suryosubroto. (2004). Manajemen Pendidikan di Sekolah. Jakarta: PT. Rieneka Cipta Creswell, John W. 2007. Qualitatif Inquiry and Research Design, Second Edition. California: Sage Publication.

Dirjen Dikdasmen Depdikbud. 1997. Pedoman Penyelenggaraan Pendidikan di Sekolah. Jakarta: Depdikbud.

Effendi, Onong Uchjana. 2003. Ilmu, Teori dan Filsafat Komunikasi. Bandung : Citra Aditya Bakti

E. Mulyasa. (2003). Manajemen Berbasis Sekolah. Bandung: PT. Remaja Rosdakarya

Hartati Sukirman, dkk. (1999). Administrasi dan Supervisi Pendidikan. Yogyakarta: AP FIP UNY

Hidayat. Dedy N. 2003. Paradigma dan Metodologi Penelitian Sosial Empirik Klasik, (Jakarta: Departemen Ilmu Komunikasi FISIP Universitas Indonesia)

Kriyantono, Rachmat. 2007. Teknik Praktis Riset Komunikasi. Jakarta: Kencana.

Kuswarno, Engkus. 2008. Etnografi Komunikasi Pengantar dan Contoh Penelitiannya. Widjaya Padjajaran: Bandung

Liliweri, Alo. 2011. Komunikasi Serba Ada Serba Makna. Kencana Prenada Media Group : Jakarta.

Moekijat. 1993. Teori Komunikasi. Bandung : Mandar Maju.

Moleong, Lexy. 2007. Metode Penelitian Kualitatif. Remaja Rosdakarya: Bandung

Mulyana, Deddy . 2003. Metodologi Penelitian Kualitatif, (Bandung: PT. Remaja Rosdakarya)

Miles, Matthew B, dan Huberman, A. Michael. 1992. Qualitative Data Analysis. (Terjemahan: Tjetjep Rohendi dengan judul: Analisis Data Kualitatif), UI-Press: Jakarta

Oktariany, dkk. 2015. Strategi Peningkatan Mutu Pendidikan Menggunakan Diagram Ishikawa Di Sma Negeri 1 Suruh. Prosiding Semiar Nasional Pendidikan Ekonomi \& Bisnis Fakultas Keguruan dan Ilmu Pendidikan. Universitas Sebelas Maret Surakarta

Rakhmat, Jalaluddin, 2005. Psikologi Komunikasi. Bandung: PT.Remaja Rosdakarya Ruslan, Rosady. 2003. Metode Penelitian PR dan Komunikasi. Jakarata : PT. Raja Grafindo Persada.

Santoso, Megawati, Dkk. 2015. Kerangka Kualifikasi Nasional Indonesia. Dokumen 001 Ristekdikti. Direktorat Jendral Pembelajaran Dan Kemahasiswaan Kementerian Riset, Teknologi, Dan Pendidikan Tinggi Republik Indonesia

Sugiyono. 2001, Metode Penelitian Administrasi, Penerbit Alfabeta Bandung (2009). Metode Penelitian Pendidikan. Bandung : Alfabeta.

. 2013. Memahami Penelitian Kuantitatif Kualitatif, cet 8. Alfabeta: Bandung.

Suharsimi Arikunto. (2010). Prosedur Penelitian Suatu Pendekatan Praktik. Jakarta : Rineka Cipta.

Syafaruddin, 2002, Manajemen Mutu dalam Pendidikan Konsep, Strategis, dan Aplikasi, Jakarta: Grasindo Gramedia Widia Sarana Indonesia.

Widjaja, A.W. 2008. Komunikasi: Komunikasi dan Hubungan Masyarakat. Bumi Aksara: Jakarta 
Yusup, Pawit M. 1989. "Komunikasi Pendidikan dan Komunikasi Instruksional". Bandung : Remaja Rosdakarya.

Yusuf, Pawit M. 2010. Komunikasi Instruksional: Teori dan Praktik. Jakarta: Bumi Aksara.

\section{Government Document}

Peraturan Pemerintah No. 24 tahun 2007 Tentang Standar Sarana Dan Prasarana Undang-Undang Republik Indonesia Nomor 20 Tahun 2003 Tentang Sistem Pendidikan Nasional

\section{Journals}

Asmawi, M. Rosul. 2005. Strategi Meningkatkan Lulusan Bermutu di Perguruan Tinggi. Universitas Islam Syekh -Yusuf. Jurnal Makara, Sosial Humaniora, Vol. 9, No. 2, Desember 2005: 66-71

Simbolon, Freddy. Pengukuran Kualitas Layanan Di Universitas Kristen Indonesia (UKI). BINUS Unversity. JURNAL Ilmiah BINUS BUSINESS REVIEW Vol. 3 No. 2 November 2012: 944-958.

Slamet, Yulius. 2006. Study Kasus: Sebuah Pendekatan Penelitian Kualitatif. Solo

\section{Website}

Hadiyanto \& Subijanto. (2003). Pengembalian kebebasan guru untuk mengkreasi iklim kelas dalam manajemen berbasis sekolah (http//:www.depdiknas.go.id)

Universitas Kristen Indonesia. Sejarah Universitas. (http://www.uki.ac.id/halaman/index/20171010-sejarah-universitas, jam 16.05 WIB, tanggal 3 April 2018) 